\title{
Effect of acidulated levels and application techniques of rock phosphate on phosphorus use efficiency and yield of wheat in calcareous soil of Peshawar-Pakistan
}

\author{
Mujibur Rahman, Dost Muhammad, Maria Mussarat, Muhammad \\ Sharif, Muhammad Irfan, Rafiullah*, Jamil Ahmad and Farooq Ishaq \\ Department of Soil and Environmental Sciences, The University of Agriculture Peshawar, Pakistan \\ *Corresponding author's email: rafiullah@aup.edu.pk \\ Citation \\ Mujibur Rahman, Dost Muhammad, Maria Mussarat, Muhammad Sharif, Muhammad Irfan, Rafiullah, Jamil \\ Ahmad and Farooq Ishaq. Effect of acidulated levels and application techniques of rock phosphate on \\ phosphorus use efficiency and yield of wheat in calcareous soil of Peshawar-Pakistan. Pure and Applied \\ Biology. Vol. 7, Issue 3, pp1094-1103. http://dx.doi.org/10.19045/bspab.2018.700128
}

\begin{tabular}{llll}
\hline \hline Received: 28/04/2018 & Revised: 20/07/2018 & Accepted: 23/07/2018 & Online First: 03/08/2018 \\
\hline
\end{tabular}

\section{Abstract}

The present study investigated the effect of different levels of acidulated rock phosphate (RP), liquid or solid and application methods on phosphorus use efficiency and wheat yield under calcareous soils of Peshawar during 2015-16. Treatments included acidulation of $100 \mathrm{~kg}$ RP with $7.5,15,30$ and $45 \mathrm{~kg} \mathrm{H}_{2} \mathrm{SO}_{4}$ equivalent to $25,50,100$ and $150 \%$ acidulation, applied in the form of either liquid or solid as single (no split) or two equal splits at sowing and knee height stage. The rate of $\mathrm{P}$ in all treatment was equal to $90 \mathrm{~kg} \mathrm{P}_{2} \mathrm{O}_{5} \mathrm{ha}^{-1}$. Our results showed that acidulation levels significantly increased wheat yield, post-harvest soil and plant tissue phosphorus optimum at $100 \%$ acidulation level. Solid form of the acidulated RP was more effective than liquid revealing that lesser the contact of soil, could improve $\mathrm{P}$ availability from the source. It was further affirmed by the split application where it significantly increased the crop yield and $\mathrm{P}$ availability over no split irrespective of solid and liquid form. Our results suggest that solid RP with $100 \%$ acidulation applied in two splits improved the crop yield, $\mathrm{P}$ use efficiency and could substitute commercial fertilizers under the prevailing soil and agroclimactic conditions.

Keywords: Acidulated rock phosphate; Application methods; Calcareous soils; Solid and liquid

\section{Introduction}

The soils of Pakistan are deficient in available phosphorus (24), mainly associated to alkalinity and calcareousness where it forms complexes with $\mathrm{Ca}$ and $\mathrm{Mg}$ (8). Nearly 90 percent of Pakistani soils are alkaline $(\mathrm{pH}>7.0)$ or calcareous $(\mathrm{CaCO} 3>$ $3.0 \%$ ) besides low level of phosphorus. When phosphorus fertilizers are applied, a small amount of phosphorus becomes available to plant while the rest goes to unavailable forms. Soil solution $\mathrm{P}$ is readily available source [1] but it is highly vulnerable to make complexes with cations like $\mathrm{Fe}, \mathrm{Al}, \mathrm{Ca}$ and $\mathrm{Mg}$ or adsorbed on the soil matrix [2]. Its deficiency causes stunted growth and delay in maturity (24,31 and 20 ). Use of $\mathrm{P}$ fertilizers assures higher yield 
production if the method of fertilizer application is proper and on time [3].To alleviate adequate supply of $\mathrm{P}$ fertilizer, use of rock phosphate could be the most affordable option in poor farming society. Each year millions of rupees are spent on import of phosphatic fertilizers to Pakistan. It is a good idea to use local deposits of RP that will not only increase crop production but will also save money. In Pakistan deposits of rock phosphate (RP) are located in Hazara and Khyber Pakhtunkhwa. However, the direct application of RP in our alkaline calcareous condition may not be fruitful. In many areas of the world it is applied directly but its solubility is very low $(<1 \%)$ in soil solution, hence unable for plant to uptake [4]. Researchers have tried to improve the solubility of RP by mixing $\mathrm{RP}$ with various organic and inorganic materials before application to soil. These amendments and materials include farmyard manure, composts, effective micro-organism (EM), acids, methods and time of applications. The alternate option could be converting insoluble $\mathrm{P}$ in RP to soluble $\mathrm{P}$ by treating RP with phosphoric acid, nitric acid or sulphuric acid along with sufficient amount of water to improve reaction. Promising results were obtained by applying acidulated RP to wheat and maize crops under alkaline calcareous soils [5]. However, acids cost and availability in market can also be considered for viable economical recommendations. Acidification of RP with different levels of sulphuric acid $\left(\mathrm{H}_{2} \mathrm{SO}_{4}\right)$ or nitric acids $\left(\mathrm{HNO}_{3}\right)$ leads to the formation of mixture of water and citrate soluble and insoluble $\mathrm{P}$ and increase dissolution of P from RP [6]. Partially acidulated RP can be obtained by treating $\mathrm{RP}$ with limited acids $(\mathrm{HCl}$ or $\mathrm{H}_{2} \mathrm{SO}_{4}$ ). However, with increase in acid levels produced more water and citrate soluble phosphate as compared to 25 and $50 \%$ acidulation [6]. After treatment of acids with RP, granules were prepared from the mixture, dried and used for application. The whole purpose of all the strategies is to improve efficiency and availability of $\mathrm{P}$ to standing crops, for higher yield and food security. Thus, the objectives of the present study were to investigate, (1) the effect of different levels of acidulated rock phosphate (RP), (2) applied liquid or solid, (3) and application methods on P use efficiency and wheat yield.

\section{Materials and methods Field experiment}

A field experiment was conducted at Newly Developmental Farm, The University of Agriculture Peshawar, Pakistan during 2015-2016. The soil of experimental field was alkaline, strongly calcareous but nonsaline in reaction with $\mathrm{pH}$, lime and $\mathrm{EC}$ values of $7.79,17.3 \%$ and $0.19 \mathrm{dS} \mathrm{m}{ }^{-1}$, respectively. Furthermore, the soil under study was deficient in organic carbon $(0.53 \%)$ and AB-DTPA extractable P (1.98 $\left.\mathrm{mg} \mathrm{kg}^{-1}\right)$. Such soils haven been reported to be highly responsive to $\mathrm{P}$ fertilizer application [1]. Four levels of acids $(25,50$, 100 and $150 \%$ ) along with two forms of rock phosphate (RP) fertilizers (liquid and solid) were applied to soil either in single dose or in two split applications. The experiment was laid out in factorial Randomized Complete Block Design (RCBD) with three replications. Siran wheat variety was sown in plot size of $3 \mathrm{~m}$ $\times 3.5 \mathrm{~m}$ with row-row distance of $30 \mathrm{~cm}$ at optimum soil moisture condition. At sowing time, the required amount of acidulated RP was applied to soil as broadcast in case of solid and spray in case of liquid. The remaining half of the split doses (solid and liquid) were banded in the rows. The field was irrigated just after 2 nd split application. In all cases, the treatments received equal net amount of acidulated RP as $90 \mathrm{~kg} \mathrm{P} 2 \mathrm{O} 5 \mathrm{ha}^{-1}$. All plots received basal doses of $\mathrm{N}$ and $\mathrm{K}$ as a urea and Murate of Potash (MOP). The field was irrigated according to weather condition and when needed.

\section{Acidification of Rock Phosphate (RP)}

For acidulation of RP, the grinded $100 \mathrm{~kg}$ $\mathrm{RP}$ was treated with the require amount of $7.5,15,30$ and $45 \mathrm{~kg} \mathrm{H}_{2} \mathrm{SO}_{4}$ along with sufficient amount of water equivalent to 25 , 
50, 100 and $150 \%$ respectively. The acidification of both solid and liquid form was done at 4 levels on the basis of complete reaction/dissolution of $\mathrm{P}$ in the RP. Usually the SSP fertilizers are prepared on commercial scale at 100:60 RP: $\mathrm{H}_{2} \mathrm{SO}_{4}$ water for highest dissolution of RP $[6,7]$.

\section{Soil analysis}

Soil sample from 0-20 $\mathrm{cm}$ depth were collected at spiking and post-harvest stage to evaluate the treatment role in $\mathrm{P}$ status of the soil. Soil $\mathrm{pH}$ and AB-DTPA extractable $P$ in soil were determined according to previously reported methods [8].

\section{Plant analysis}

At harvesting time, one square meter was randomly selected in each plot for measuring dry matter yield and grain yield. Furthermore, leaves samples at plant maturity stage were collected for measuring nutrient concentrations. Leaves were washed with distilled water, air dried in oven at $60-70^{\circ} \mathrm{C}$ for $48 \mathrm{~h}$. After grinding, the samples were digested with nitric acid $\left(\mathrm{HNO}_{3}\right)$ and perchloric acid $\left(\mathrm{HClO}_{4}\right)$ as described by [8]. Then, $\mathrm{P}$ concentration was determined by using spectrophotometer.

\section{Results and discussion Grain yield}

The wheat grain yield was significantly increased by extent of acidulation, forms of RP fertilizer (solid and liquid) and application methods; however their interactions were non-significant at $\mathrm{p}<$ 0.05 (Table 1). When the values were averaged across the time of application and form of acidulated RP, acidulated RP of 100 and $150 \%$ produced grain yield (3857 $\mathrm{kg} \mathrm{ha}^{-1}$ ) and (3966 kg ha-1) which were higher than $25 \%$ acidified RP with grain yield of $2884 \mathrm{~kg} \mathrm{ha}^{-1}$. When the values were averaged across acidulation levels and time of application, the granular solid fertilizer produced higher grain yield $\left(3611 \mathrm{~kg} \mathrm{ha}^{-1}\right)$ over the liquid fertilizer (3393 $\left.\mathrm{kg} \mathrm{ha}^{-1}\right)$.In application methods, split doses of RP lead to comparatively more yield $3681 \mathrm{~kg} \mathrm{ha}^{-1}$ than no split application (3324 $\left.\mathrm{kg} \mathrm{ha}^{-1}\right)$ on average basis. As the yield parameters are directly associated with availability of phosphorus, acidulated RP could release $\mathrm{P}$ in a better way for plant growth. Similar results were also reported by $[9,10]$ that acidulation of RP resulted in better grain yield. The higher performance of the solid RP could be attributed to less contact of granular RP against the liquid acidified RP where much of it would have been adsorbed on the matrix or formed complexes with $\mathrm{Ca}$ and $\mathrm{Mg}$ in the prevailing alkaline soil [11]. The performance of solid than liquid RP may be due the better placement of the $P$ fertilizer which influences the growth parameter positively and increased grain yield, where $\mathrm{P}$ applied in solid form as described by Ali et al. (2004). Our results are also comparable with [12-14] who reported that $\mathrm{P}$ applied as a split dose at planting stage or different growth stages by the method of side dressing, or 2nd application with irrigation, resulted more grain yield as compared to full application at sowing time. Similar findings were also reported by [15-18].

\section{Dry matter yield}

Dry matter yield of wheat was significantly increased over control with acidulation levels of RP, forms of $\mathrm{P}$ fertilizers and application methods at $\mathrm{P}<0.05$ (Table 2). The interactions were non-significant. The plots receiving 100 and $150 \%$ acidified RP gave higher dry matter yield of $8534 \mathrm{~kg} \mathrm{ha}$ 1 and $8748 \mathrm{~kg} \mathrm{ha}^{-1}$ respectively, while lowest was obtained $5362 \mathrm{~kg} \mathrm{ha}^{-1}$ in control plots. It is suggested that $100 \%$ acidulation was sufficient for full acidification of RP in term of plant growth. Furthermore, liquid RP produced lower dry matter yield (7476 $\mathrm{kg} \mathrm{ha}^{-1}$ ) while solid RP produced higher dry matter yield (8135 $\mathrm{kg} \mathrm{ha}^{-1}$ ) respectively. Regarding application methods, split application yielded $7969 \mathrm{~kg} \mathrm{ha}^{-1}$ dry matter yield as compared to $7643 \mathrm{~kg} \mathrm{ha}^{-1}$ with no split application when values were averaged over acidulation levels and forms of RP fertilizers. Application of RP+50 \% acid enhanced biomass yield of wheat crop as compared with other $\mathrm{P}$ fertilizer suggesting that acidulation could be the best option under prevailing soil situation 
[9]. The best performance of $100 \%$ acid level with RP could be due to more release of $\mathrm{P}$ from RP for plants as concluded by [19-21] that increase $\mathrm{H}_{2} \mathrm{SO}_{4}$ concentration in RP, releases more $\mathrm{P}$ for plants. Solid fertilizer was found superior an improving wheat yield and yield components. This may be because of better availability of $\mathrm{P}$ to wheat roots, as RP granules were properly incorporated into soil through deep placement, and irrigation was done on time $[22,23]$. Split application of $P$ fertilizers with deep placement method (banding) increased the biomass yield of wheat crop $[1,24]$.

Table 1. Grain yield of wheat as affected by different acid levels, forms of rock phosphate fertilizer and application methods

\begin{tabular}{|c|c|c|c|c|}
\hline \multirow{3}{*}{ Application Methods } & \multicolumn{4}{|c|}{ Grain Yield $\left(\mathrm{kg} \mathrm{ha}^{-1}\right)$} \\
\hline & \multirow{2}{*}{$\%$ Acidity } & \multicolumn{2}{|c|}{ Fertilizer Forms } & \multirow{2}{*}{ Mean } \\
\hline & & Liquid & Solid & \\
\hline & 25 & 2802 & 2966 & $2884 \mathrm{c}$ \\
\hline & 50 & 3116 & 3487 & $3301 \mathrm{~b}$ \\
\hline & 100 & 3767 & 3947 & $3857 \mathrm{a}$ \\
\hline & 150 & 3888 & 4045 & 3966 a \\
\hline No Split & & 3194 & 3454 & $3324 \mathrm{~b}$ \\
\hline \multirow[t]{2}{*}{ Split } & & 3592 & 3769 & $3681 \mathrm{a}$ \\
\hline & Mean & $3393 \mathrm{~b}$ & $3611 \mathrm{a}$ & Significance \\
\hline \multicolumn{2}{|c|}{ Planned Mean Comparison } & & & $* * *$ \\
\hline Control & 2571 & & & \\
\hline Rest & 3502 & & & \\
\hline $\operatorname{LSD}(0.05)$ & & Interactions & & \\
\hline Fertilizer Forms $(\mathrm{F})$ & $* * *$ & F x AM & & $\mathrm{NS}$ \\
\hline App. Methods (AM) & $* * *$ & $\mathrm{~F} \times \mathrm{L}$ & & NS \\
\hline \multirow[t]{2}{*}{ Acid Levels (L) } & 155 & AM x L & & NS \\
\hline & & F x AM x L & & $\mathrm{NS}$ \\
\hline
\end{tabular}

Table 2. Dry matter yield of wheat crop as influence by various degrees of acidulation, forms of RP fertilizers and application methods

\begin{tabular}{|c|c|c|c|c|}
\hline & \multicolumn{3}{|c|}{ Dry matter Yield (kg ha-1) } \\
\hline \multirow{2}{*}{ Application Methods } & \multirow{2}{*}{ \% Acidity } & Fertilizer Forms & \multirow{2}{*}{ Mean } \\
\cline { 3 - 4 } & 25 & 6012 & 6392 & $6202 \mathrm{c}$ \\
\hline & 50 & 7410 & 7822 & $7616 \mathrm{~b}$ \\
\hline & 100 & 8168 & 8597 & $8382 \mathrm{a}$ \\
\hline & 150 & 8427 & 8781 & $8604 \mathrm{a}$ \\
\hline No Split & & 7163 & 7508 & $7336 \mathrm{~b}$ \\
\hline Split & Mean & 7846 & 8287 & $8067 \mathrm{a}$ \\
\hline \multicolumn{2}{|c|}{} & $7504 \mathrm{~b}$ & $7898 \mathrm{a}$ & \\
\hline Planned Mean Comparison & & & \\
\hline Control & 5362 & & & \\
\hline Rest & 7701 & Interactions & & \\
\hline LSD(0.05) & $* * *$ & F x AM & & NS \\
\hline Fertilizer Forms (F) & $* * *$ & F x L & & NS \\
\hline App. Methods (AM) & 300 & AM x L & & NS \\
\hline Acid Levels (L) & & F x AM x L & & NS \\
\hline \multicolumn{2}{|c|}{} & &
\end{tabular}




\section{Post-harvest soil pH}

The post-harvest soil $\mathrm{pH}$ as influenced by acidification levels of RP, forms of RP fertilizers and application methods showed non-significant result and their interactions were also found non-significant except only the controls vs rests showed slightly significant result (Table 3). Control plots had significantly higher $\mathrm{pH}$ with value of 7.70 as compared to the overall mean of all treatments with value of 7.56 indicating that $\mathrm{P}$ fertilizer reduced the soil $\mathrm{pH}$ at postharvest stage of the crop. The decrease in the $\mathrm{pH}$ could be associated to $\mathrm{CaSO}_{4}$ by production during the reaction of $\mathrm{RP}$ with $\mathrm{H}_{2} \mathrm{SO}_{4}$ as well as to surplus acid remained unreactive in the process. However, the $\mathrm{pH}$ changes among the treatments were nonsignificant that could be due to higher changes among the replications. It has been reported that Pakistani soils are mostly alkaline in reactions with $\mathrm{pH}$ ranges from 7.5 to 8.5. The reason for this may be the calcareous parent materials $(90 \%$ soils of Pakistan are calcareous [25] which include $\mathrm{Ca}^{2+}, \mathrm{Mg}^{2+}, \mathrm{SO}_{4}{ }^{2-}, \mathrm{CO}_{3}{ }^{2-}$ and $\mathrm{HCO}_{3}{ }^{2-}$ as well as greater proportion of $\mathrm{OH}^{-}$than $\mathrm{H}^{+}$ ions in soil solution. These ions induce higher soil buffering capacity and make it difficult to change the soil $\mathrm{pH}$ substantially. The application of $\mathrm{P}$ fertilizers decrease soil $\mathrm{pH}$ up to some extent but due high $\mathrm{Ca}$ and $\mathrm{Mg}$ content along with high buffering capacity cannot decrease the soil $\mathrm{pH}$ at greater extent but there may be decreasing trend with $\mathrm{P}$ fertilizer as compared to no $\mathrm{P}$ fertilizers application $[26,27]$.

Table 3. Soil post-harvest $\mathrm{pH}$ reading as affected by various degree of acidulation, form of RP fertilizer and application methods

\begin{tabular}{|c|c|c|c|c|}
\hline \multirow{3}{*}{ Application Methods } & \multicolumn{3}{|c|}{ Post-Harvest soil pH } & \multirow{3}{*}{ Mean } \\
\hline & \multirow{2}{*}{ \% Acidity } & \multicolumn{2}{|c|}{ Fertilizer Forms } & \\
\hline & & Liquid & Solid & \\
\hline & 25 & 7.59 & 7.63 & $7.61 \mathrm{a}$ \\
\hline & 50 & 7.61 & 7.48 & $7.54 \mathrm{a}$ \\
\hline & 100 & 7.51 & 7.58 & $7.54 \mathrm{a}$ \\
\hline & 150 & 7.58 & 7.56 & $7.57 \mathrm{a}$ \\
\hline No Split & & 7.55 & 7.56 & $7.56 \mathrm{a}$ \\
\hline \multirow[t]{2}{*}{ Split } & & 7.59 & 7.55 & $7.57 \mathrm{a}$ \\
\hline & Mean & $7.57 \mathrm{a}$ & $7.56 \mathrm{a}$ & Significance \\
\hline Planned Mean Comparison & & & & $*$ \\
\hline Control & 7.70 & & & \\
\hline Rest & 7.56 & & & \\
\hline LSD $(0.05)$ & & Interactions & & \\
\hline Fertilizer Forms $(\mathrm{F})$ & NS & F x AM & & NS \\
\hline App. Methods (AM) & NS & $\mathrm{F} \times \mathrm{L}$ & & NS \\
\hline \multirow[t]{2}{*}{ Acid Levels (L) } & 0.08 & AM $\times$ L & & NS \\
\hline & & F x AM x L & & NS \\
\hline
\end{tabular}

\section{Soil AB-DTPA extractable phosphorus at boot stage of wheat}

The soil AB-DTPA extractable $\mathrm{P}$ was significantly influenced by various acid levels, form of RP fertilizers and application methods and their interactions were found non-significant except between application methods and acid levels (AM $\mathrm{x}$ L) (Table 4). The AB-DTPA extractable phosphorus at boot stage of wheat was increased with increasing acidulation levels of RP. At $150 \%$ acidulation, the soil $\mathrm{P}$ was $4.84 \mathrm{mg} \mathrm{kg}-1$ which was similar to $4.15 \mathrm{mg}$ P kg-1 observed in $100 \%$ acidulated RP on average basis. The $25 \%$ acidulated RP produced $2.32 \mathrm{mg} \mathrm{kg}-1 \mathrm{P}$ which was higher than $1.57 \mathrm{mg} \mathrm{kg-1}$ recorded for control. Regarding the solid and liquid forms of 
acidulated RP, solid fertilizers were found superior as compared to liquid fertilizer. In solid fertilizers, the $\mathrm{P}$ was $4.30 \mathrm{mg} \mathrm{kg}-1$ while in case of liquid acidulated RP it was $2.92 \mathrm{mg} \mathrm{kg}-1$ at boot stage of wheat crop. Among the application methods, split application showed significantly higher values of $3.92 \mathrm{mg} \mathrm{kg}-1$ as compared to no split application giving value of $3.30 \mathrm{mg}$ $\mathrm{kg}-1$ at boot stage of wheat.

The increase in soil $\mathrm{P}$ concentration affirmed higher release of $\mathrm{P}$ with acidulation of RP as also reported by $[6,9]$.
The solid fertilizers increased the soil $\mathrm{P}$ over the liquid fertilizer that could be associated of less contact with soil colloids. Similar results were also reported by [13]. This was further affirmed by the splitting of fertilizer which further reduced the contact time between the $\mathrm{P}$ in solution with soil colloids and hence reduced the $\mathrm{P}$ fixation and complexation that usually increased with time and more contact of $\mathrm{P}$ fertilizer with soil. These results are in line with [6] who reported that there will be more $\mathrm{P}$ in soil after split application of $\mathrm{P}$ fertilizers.

Table 4. Soil AB-DTPA extractable phosphorus at boot stage of the wheat crop as affected by various degree of acidulation, form of RP fertilizer and application methods

\begin{tabular}{|c|c|c|c|c|}
\hline \multicolumn{5}{|c|}{ AB-DTPA Extractable P $\left(\mathrm{mg} \mathrm{kg}^{-1}\right)$} \\
\hline \multirow{2}{*}{ Application Methods } & \multirow{2}{*}{$\%$ Acidity } & \multicolumn{2}{|c|}{ Fertilizer Forms } & \multirow{2}{*}{ Mean } \\
\hline & & Liquid & Solid & \\
\hline & 25 & 1.98 & 2.66 & $2.32 \mathrm{~d}$ \\
\hline & 50 & 2.23 & 4.03 & $3.13 \mathrm{c}$ \\
\hline & 100 & 3.65 & 4.64 & $4.15 \mathrm{~b}$ \\
\hline & 150 & 3.81 & 5.87 & $4.84 \mathrm{a}$ \\
\hline No Split & & 2.42 & 4.17 & $3.30 \mathrm{~b}$ \\
\hline \multirow[t]{2}{*}{ Split } & & 3.41 & 4.43 & $3.92 \mathrm{a}$ \\
\hline & Mean & $2.92 \mathrm{~b}$ & $4.30 \mathrm{a}$ & Significance \\
\hline \multicolumn{2}{|c|}{ Planned Mean Comparison } & & & $* * *$ \\
\hline Control & 1.57 & & & \\
\hline Rest & 3.61 & & & \\
\hline $\operatorname{LSD}(0.05)$ & & Interactions & & \\
\hline Fertilizer Forms (F) & $* * *$ & Fx AM & & NS \\
\hline App. Methods (AM) & $*$ & $\mathrm{~F} \times \mathrm{L}$ & & NS \\
\hline \multirow[t]{2}{*}{ Acid Levels (L) } & 0.66 & $\mathrm{AM} \times \mathrm{L}$ & & $*$ \\
\hline & & F x AM x L & & NS \\
\hline
\end{tabular}

\section{Post-harvest soil AB-DTPA extractable $\mathbf{P}$}

Like the AB-DTPA extractable P in boot stage of the crop, the postharvest soil ABDTPA extractable $P$ was also significantly affected by acidulation levels while nonsignificantly by forms of RP fertilizer, application methods and their interactions produced non-significant result. When control was compared, the treated plots had significantly higher AB-DTPA extractable $P$ concentration at postharvest stage than control receiving non-acidulated RP suggesting that acidulation increased the $\mathrm{P}$ release from the RP (Table 5). The minimum value $1.26 \mathrm{mg} \mathrm{kg}^{-1}$ was observed in controls plots while maximum value 2.28 $\mathrm{mg} \mathrm{kg}^{-1}$ was recorded in treated plots. This increase from RP increased with acid levels and higher value of post-harvest soil ABDTPA extractable $\mathrm{P}$ as $2.77 \mathrm{mg} \mathrm{kg}^{-1}$ was noted in $150 \%$ acidulated RP when averaged across the forms and application method. This was followed by $100 \%$ levels $2.61 \mathrm{mg} \mathrm{kg}-1$ while lower value of $1.67 \mathrm{mg}$ $\mathrm{kg}-1$ was recorded for $25 \%$ acid levels. The soil AB-DTPA extractable P decreased gradually from boot stage of the crop to 
post-harvest stage indicating reduction with time associated with plant uptake and fixation that increased with time. The increased in soil AB-DTPA with RP acidulation was also reported by [6] in the same soils of Peshawar.

Table 5. Post-harvest soil AB-DTPA extractable phosphorus as affected by various degree of acidulation, form of RP fertilizer and application methods

\begin{tabular}{|c|c|c|c|c|}
\hline \multicolumn{5}{|c|}{ Post- Harvest Soil AB-DTPA Extractable P $\left(\mathrm{mg} \mathrm{kg}^{-1}\right)$} \\
\hline \multirow{2}{*}{ Application Methods } & \multirow{2}{*}{$\%$ Acidity } & \multicolumn{2}{|c|}{ Fertilizer Forms } & \multirow{2}{*}{ Mean } \\
\hline & & Liquid & Solid & \\
\hline & 25 & 1.55 & 1.79 & $1.67 \mathrm{c}$ \\
\hline & 50 & 2.07 & 2.10 & $2.09 \mathrm{~b}$ \\
\hline & 100 & 2.47 & 2.74 & $2.61 \mathrm{a}$ \\
\hline & 150 & 2.56 & 2.97 & $2.77 \mathrm{a}$ \\
\hline No Split & & 2.10 & 2.30 & $2.20 \mathrm{a}$ \\
\hline Split & & 2.23 & 2.51 & $2.37 \mathrm{a}$ \\
\hline & Mean & $2.16 \mathrm{a}$ & $2.40 \mathrm{a}$ & \\
\hline \multicolumn{2}{|c|}{ Planned Mean Comparison } & & & Significance \\
\hline Control & 1.26 & & & $* * *$ \\
\hline Rest & 2.28 & & & \\
\hline LSD $(0.05)$ & & Interactions & & \\
\hline Fertilizer Forms (F) & NS & $\mathrm{F} \times \mathrm{AM}$ & & NS \\
\hline App. Methods (AM) & NS & $\mathrm{F} \times \mathrm{L}$ & & NS \\
\hline \multirow[t]{2}{*}{ Acid Levels (L) } & 0.337 & AM x L & & NS \\
\hline & & F x AM x L & & NS \\
\hline
\end{tabular}

\section{$P$ concentration in plant leaves}

The $\mathrm{P}$ concentration in plant leaves was significantly influenced by various acidulation levels and application methods while effect of forms of RP fertilizers (solid and liquid), increased $\mathrm{P}$ concentration in plant leaves over control but the difference between the two forms was statistically non-significant (Table 6). Among the acid levels, 100 and $150 \%$ were found superior and more $\mathrm{P}$ concentration was recorded in plant leaves which are 0.146 and $0.148 \%$ respectively. When averaged across the forms of fertilizers and application technique, the minimum $\mathrm{P}$ concentration $0.116 \%$ was observed at $25 \%$ acidified RP. In case of application methods, split application showed more $\mathrm{P}$ concentration $0.145 \%$ while lower $\mathrm{P}$ accumulation in leaves $0.124 \%$ was noted in single application. All treated plots produced higher $\mathrm{P}$ concentration in wheat leaves at harvesting stage over the control which received the non-acidulated RP suggesting that acidulation of RP substantially improved the $\mathrm{P}$ release from RP and its availability to plant. The interactions of the treatments produced no significant result. Our results are in line with [6], that acidulation of RP increased the $\mathrm{P}$ concentration in plants leaves.

The split application of RP to reduced contact time between the soil colloids and soil particles increased the $\mathrm{P}$ release and enhanced the $\mathrm{P}$ concentration in wheat leaves when compared to no-split. However the $\mathrm{P}$ concentration in leaves did not differs much in solid and liquid fertilizers, which could be concerned to growth variations. Similar results were obtained by [28]. Higher P concentration was recorded when $\mathrm{P}$ was applied in split doses to wheat crop [29].

\section{$P$ concentration in grains}

The $\mathrm{P}$ concentration in wheat grains was significantly increased with increasing acidification level of RP and split application while the difference between the liquid and solid acidulated RP was found non-significant while the interactions 
were found non-significant (Table 7). Results indicated that $\mathrm{P}$ concentration in grain significantly increased with increasing acidification levels. More $\mathrm{P}$ concentration $0.17 \%$ was recorded in 150 $\%$ acid levels followed $100 \%$ acid level while lower $\mathrm{P}$ concentration $0.14 \%$ was observed in $25 \%$ acidification level. Among the application methods, split application produced more $\mathrm{P}$ concentration $0.16 \%$ in grains over no split which was recorded $0.15 \%$. Similarly treated plots showed more $\mathrm{P}$ accumulation $0.15 \%$ in grains as compared to controls plots $0.11 \%$ when averaged across all factors.
The higher $\mathrm{P}$ concentration in grain reflected the higher availability of $\mathrm{P}$ in soil which would have been increased with acidulation levels and time of application. Similar to P concentration in wheat leaves, the $\mathrm{P}$ concentration in grains also increased in split application which may be due to the deep placement of RP fertilizers in the 2 nd application time that would have reduced the roots and granule distances and facilitated the $\mathrm{P}$ availability. Split application of phosphorus fertilizers caused higher $\mathrm{P}$ concentration in grains of wheat [29].

Table 6. Plant leaves $P$ concentrations as affected by various degree of acidulation, form of RP fertilizer and application methods

\begin{tabular}{|c|c|c|c|c|}
\hline \multirow{3}{*}{ Application Methods } & \multirow{3}{*}{$\%$ Acidity } & \multicolumn{3}{|c|}{ Plant leaves $P$ concentration $(\%)$} \\
\hline & & \multicolumn{2}{|c|}{ Fertilizers Forms } & \multirow{2}{*}{ Mean } \\
\hline & & Liquid & Solid & \\
\hline & 25 & 0.111 & 0.120 & $0.116 b$ \\
\hline & 50 & 0.117 & 0.138 & $0.127 \mathrm{~b}$ \\
\hline & 100 & 0.141 & 0.151 & $0.146 \mathrm{a}$ \\
\hline & 150 & 0.150 & 0.146 & $0.148 \mathrm{a}$ \\
\hline No Split & & 0.122 & 0.126 & $0.124 \mathrm{~b}$ \\
\hline \multirow[t]{2}{*}{ Split } & & 0.138 & 0.151 & $0.145 \mathrm{a}$ \\
\hline & Mean & $0.130 \mathrm{a}$ & $0.139 \mathrm{a}$ & \\
\hline \multicolumn{2}{|c|}{ Planned Mean Comparison } & & & Significance \\
\hline Control & 0.100 & & & $* *$ \\
\hline Rest & 0.134 & & & \\
\hline LSD $(0.05)$ & \multicolumn{3}{|c|}{ Interactions } & \\
\hline Fertilizer Forms $(\mathrm{F})$ & NS & $\mathrm{F} \times \mathrm{AM}$ & & NS \\
\hline App. Methods (AM) & $* *$ & $\mathrm{~T} \times \mathrm{L}$ & & $\mathrm{NS}$ \\
\hline \multirow[t]{2}{*}{ Acid Levels (L) } & 0.0171 & AM x L & & NS \\
\hline & & F x AM x L & & NS \\
\hline
\end{tabular}

Table 7. Wheat grain $P$ concentrations as affected by various degree of acidulation, form of RP fertilizer and application methods

\begin{tabular}{|c|c|c|c|c|}
\hline \multirow{2}{*}{ Application Methods } & \multirow{4}{|c|}{ Grain P Concentration (\%) } \\
\cline { 3 - 4 } & \multirow{2}{*}{ \% Acidity } & Liquid & Solid & \multirow{2}{*}{ Mean } \\
\cline { 3 - 4 } & 25 & 0.145 & 0.139 & $0.142 \mathrm{c}$ \\
\hline & 50 & 0.153 & 0.158 & $0.155 \mathrm{bc}$ \\
\hline & 100 & 0.156 & 0.175 & $0.166 \mathrm{ab}$ \\
\hline & 150 & 0.165 & 0.176 & $0.171 \mathrm{a}$ \\
\hline No Split & & 0.143 & 0.157 & $0.150 \mathrm{~b}$ \\
\hline Split & & 0.167 & 0.167 & $0.167 \mathrm{a}$ \\
\hline \multicolumn{2}{|c|}{ Planned Mean Comparison } & $0.155 \mathrm{a}$ & $0.162 \mathrm{a}$ & Significance \\
\hline \multicolumn{2}{|c|}{} & & & $* * *$ \\
\hline
\end{tabular}




\begin{tabular}{|c|c|c|l|c|}
\hline Control & 0.117 & & & \\
\hline Rest & 0.158 & & & \\
\hline LSD (0.05) & & Interactions & & \\
\hline Fertilizer Forms (F) & NS & F x AM & & NS \\
\hline App. Methods( AM) & $* *$ & F x L & & NS \\
\hline Acid Levels (L) & 0.014 & AM x L & & NS \\
\hline & & F x AM x L & & NS \\
\hline
\end{tabular}

\section{Conclusions}

The wheat grain and biomass yield and plant P and soil AB-DTPA extractable at postharvest stage improved with acidification suggesting that $P$ release from RP was enhanced through acidification. Solid acidulated RP showed higher efficiency as compared to the liquid fertilizer which could be attributed to less exposure and contact with soil matrices. Furthermore, split application of both solid and liquid acidified RP improved the yield and $\mathrm{P}$ uptake by wheat crop. Conclusively, solid $100 \%$ acidulated RP, applied in two equal splits is recommended for higher wheat yield and P uptake under calcareous conditions with improved technology and agronomic practices.

\section{Authors' contributions}

Conceived and designed the experiments: M Rahman, D Muhammad, M Sharif \& M Mussarat, Performed the experiments: M Rahman \& D Muhammad, Analyzed the data: M Rahman, D Muhammad \& M Sharif, Contributed reagents/ materials/ analysis tools: M Rahman, D Muhammad, RJ Ahmad \& F Ishaq, Wrote the paper: M Rahman, D Muhammad, Rafiullah \& M Irfan.

\section{References}

1. Ahmad M, Khan MJ \& Muhammad D (2013). Response of maize to different phosphorus levels under calcareous soil conditions. Sarhad J. Agric. 29:43-48.

2. Brady N \& Weil R (2002). The nature and properties of soils. 13 Edition New Jersey USA.

3. Tang X, Li J, Ma Y, Hao X \& Li X (2008). Phosphorus efficiency in long-term (15 years) wheat-maize cropping systems with various soil and climate conditions. Field Crops Res 108: 231-237.

4. Stamford N, Santos P, Santos C, Freitas A, Dias S \& Lira A (2007). Agronomic effectiveness of biofertilizers with phosphate rock, sulphur and Acidithiobacillus for yam bean grown on a Brazilian tableland acidic soil. Bioresource Technol 98: 1311-1318.

5. Naseer M \& Muhammad D (2014). Direct and residual effect of hazara rock phosphate (hrp) on wheat and succeeding maize in alkaline calcareous soils. Pak J of. Bot 46: 1755-1761.

6. Naseer M (2014). Role of rock phosphate in crop production in alkaline calcareous soil. Ph.D Thesis Department of Soil \& Environmental Sciences The Univerisity of Agriculture. Peshawar-Paktistan.

7. Khan M, Ahmad S, Sharif M, Billah S \& Aslam M (2012). Formulation of single super phosphate fertilizer from rock phosphate of Hazara, Pakistan. Soil \& Environment 31.

8. Ahmad M, Khattak RA \& Muhammad D (2014). Humic Acid and Micronutrient Effects on Wheat Yield and Nutrients Uptake in Salt Affected Soils. International J of Agric and Biol 16: 991995.

9. Khattak BU (2009). Comparative effect of sulphuric acid treated with rock phosphate and DAP on phosphorus uptake and yield of maize in calcareous soil. M.Sc.(Hons) Thesis Department of Soil \& Environmental Sciences The Univerisity of Agriculture. Peshawar-Paktistan.

10. Basak R \& De GK (1997). Release of phosphorus from partially acidulated rock phosphate in a Typic Ustifluvent. $J$ of the Indian Society of Soil Sci 45: 759-762.

11. Bohn HL, McNeal BL \& Oconnor GA (1985). Soil Chemistry. 2nd edition Wiley New York.

12. Alam SM, Shah SA \& Iqbal MM (2005). Evaluation of method and time of fertilizer application for yield and optimum Pefficiency in wheat. $J$ of Sci and Technol 27: 457-463. 
13. Alam SM, Shah SA \& Ali S (2003). Effect of time and methods of $\mathrm{P}$ application on fodder yield and $\mathrm{P}$ uptake by barseem. Pak J Soil Sci 22: 77-80.

14. Alam SM, Latif A \& Iqbal Z (2002). Wheat yield and phosphorus use efficiency as influenced by method of phosphorus and zinc application. Pak J Sci Industry Res 45: 117-119.

15. Rehman A (1975). Effect of application of $\mathrm{P}$ on the growth and yield of wheat variety Ch. 70. M.Sc Thesis University of Agriculture Faisalabad.

16. Hamid A \& Sarwar G (1977). Effect of methods and time of application on uptake of fertilizer phosphorus by wheat. Experimental Agric 13(4): 337-340.

17. Ali M, Ali L, Din M, Sattar M, Waqar MQ, Ali MA \& Khalid L (2015). Comparative performance of wheat in response to different phosphatic fertilizers. Inter J Res Agric Forestry 2:1-9.

18. Latif A, Alam SM, Iqbal Z \& Shah SA (2001). Effect of fertigation applied nitrogen and phosphorus on yield and composition of maize. Pak J of Soil Sci 19: 23-26.

19. Irfan A (2009). Rock phosphate solubility in water and sulphuric acid solution. B.Sc.(Hons) Internship Report Department Soil \& Environmental Sciences The University of Agriculture Peshawar- Pakistan.

20. Tariq M (2009). Uptake of phosphorus by wheat seedling as influenced by acidified rock phosphate in calcareous soil. B.Sc.(Hons) Internship Report Department Soil \& Environmental Sciences The University of Agriculture Peshawar- Pakistan

21. Dash RN, Mohanty SK \& Patnaik S (1981). Efficiency of $\mathrm{HCl}$ and $\mathrm{H}_{2} \mathrm{SO}_{4}$ acidulated rock phosphate for a rice based cropping system. Fertility Research India 2: 109118

22. Tisdale SL, Nelson WL \& Beaton JD 1985. Soil fertility and fertilizers. MacMillan Publishing Co. New York.

23. Turk MA \& Tawaha AM (2001). Common vetch productivity as influenced by rate and methods of phosphate placement in Mediterranean environment. Agric Mediterian 13: 108-111.

24. Bashir S, Anwar S, Ahmad B, Sarfraz Q, Khattak W \& Islam M (2015). Response of wheat crop to phosphorus levels and application methods. J of Environ \& Earth Sci 5: 9.

25. Ahmad N, Ahmad R, Bokhari S \& Ghani A (1990). Physiological determinants of growth and yield in wheat as affected by different levels of nitrogen and phosphorous. Pak J of Agric Sci 27: 390404.

26. Lambert R, Grant C \& Sauvé S (2007). Cadmium and zinc in soil solution extracts following the application of phosphate fertilizers. Sci Total Environ 378: 293-305.

27. Olatuyi S, Akinremi O, Flaten D \& Crow $G$ (2009). Accompanying cations and anions affect the diffusive transport of phosphate in a model calcareous soil system. Canadian J of Soil Sci 89: 179-188.

28. Holloway R, Bertrand I, Frischke A, Brace D, McLaughlin MJ \& Shepperd W (2001). Improving fertiliser efficiency on calcareous and alkaline soils with fluid sources of P, N and Zn. Plant Soil 236: 209-219.

29. Yaseen G, Mehboob I, Ahmad N \& Yaseen M (2005). Effect of phosphorus application time on yield and $\mathrm{P}$ use efficiency by wheat crop. $J$ of Agric Res 43(1). 